\title{
4.2. АНАЛИТИЧЕСКИЕ АСПЕКТЫ ОЦЕНКИ РИСКОВ АУДИТОРСКИХ ОРГАНИЗАЦИЙ В УСЛОВИЯХ ПЕРЕХОДА НА МЕЖДУНАРОДНЫЕ СТАНДАРТЫ АУДИТА
}

Синянская Е.Р., к.э.н., доцент, кафедра учета, анализа и аудита;

Рушева И.А., магистрант,

кафедра учета, анализа и аудита

ФГАОУ ВО «Уральский феедеральный университет имени первого Президента России Б.Н. Ельцина», г. Екатеринбург

В статье изложены материалы проведенного авторами исследования изменений на рынке аудиторских услуг с 2013 по 2017 гг., а также структурированы проблемы, возникшие в первые полтора года переходного периода на международные стандарты аудита. По результатам исследования разработана модель, позволяющая оценивать факторы риска в процессе реформирования отрасли для повышения конкурентоспособности аудиторской организации.

\section{Литература}

1. О введении в действие международных стандартов аудита на территории РФ и о признании утратившими силу некоторых приказов Министерства финансов РФ [Электронный ресурс] : приказ М-ва финансов РФ от 9 янв. 2019 г. №2н. Доступ из справ.-правовой системы «Консультант Плюс».

2. Основные показатели рынка аудиторских услуг в РФ в 2014-2017 гг. [Электронный ресурс] // М-во фринансов РФ : официальный сайт. - URL : minfin.ru/ru/perfomance/ audit/audit stat/MainIndex

3. Основные показатели деятельности саморегулируемых организаций аудиторов в 2014-2017 гг. [Электронный ресурс] // М-во финансов РФ. - URL : minfin.ru/ru/perfomance/audit/audit stat/Mainlndex selfregulation

4. Долгов А.И. и др. Стратегический менеджмент [Текст] : учеб. пособие / А.И. Долгов, Е.А. Прокопенко. - М. : ФЛИНТА, 2016. - $280 \mathrm{c}$.

5. Илышева Н.Н. и др. Учет и финансовый менеджмент: концептуальные основы [Текст] : учеб. пособие / Н.Н. Илышева, С.И. Крылов, Е.Р. Синянская. - Екатеринбург : Изд-во Урал. ун-та, 2018. - 164 с.

6. Кочинев Ю.Ю. Аудит в соответствии с международными стандартами [Текст] : учеб. / Ю.Ю. Кочинев. - М. : ИНФРА-М, 2019. -413 c.

7. Лапыгин Ю.Н. Управленческий консалтинг [Текст] : учеб. / Ю.Н. Лапыгин. - М. : ИНФРА-М, 2018. - 330 с.

8. Обязательный аудит 2019 и его альтернатива [Электронный ресурс] // Правовест Аудит : официальный сайт компании. - URL : pravovest-audit.ru/nashi-statii-nalogi-i-buhuchet/obyazatelnyy-audit-2019-i-ego-alternativa

9. Петров А.Н. и др. Проблемы внедрения международных стандартов аудита в России [Текст] / А.Н. Петров, Е.А. Иванова // Анализ и современные информационные технологии в обеспечении экономической безопасности бизнеса и государства : сб. науч. тр. и результатов совместных науч.-иссл. проектов ; РЭУ им. Г.В. Плеханова. - М., 2016. - C. 312-319.

10. Портер М. Конкурентная стратегия: Методика анализа отраслей и конкурентов [Текст] : пер. с англ. / Майкл Портер. М. : Альпина Бизнес Букс, 2005. - 454 с.

\section{Ключевые слова}

Международные стандарты аудита; аудиторские услуги; переходный период; конкурентоспособность; квалификационные требования; стратегический менеджмент; SWOT-анализ; финансовые риски; обязательный аудит; сопутствующие аудиту услуги; саморегулируемые организации.

\section{Синянская Елена Рудольфровна}

Рушева Ирина Андреевна

\section{РЕЦЕНЗИЯ}

Актуальность темы исследования обусловлена тем, что сфера аудиторских услуг в настоящее время находится в состоянии реформирования и перехода на международные стандарты аудита, что оказывает значительное влияние на деятельность аудиторских организаций и индивидуальных аудиторов. В связи с этим возникает потребность в совершенствовании аналитического и методического обеспечения руководства аудиторских организаций при оценке рисков, связанных с переходом на новую нормативную базу.

Научная новизна и практическая значимость. В работе проведен всесторонний анализ и систематизация различных аспектов теоретического и прикладного характера, обусловленных реформированием сферы аудиторских услуг за период 5 лет. Разработанная авторами методика анализа рисков может быть применена в практической деятельности аудиторских фирм для преодоления проблем переходного периода.

Заключение: рецензируемая статья отвечает требованиям, предъявляемым к научным публикациям, и может быть рекомендована к изданию.

Илышева Н.Н., д.э.Н., профессор, заведующий кафеерой учета, анализа и аудита ФГАОУ ВО «Уральский федеральный университет имени первого Президента России Б.Н. Ельцина», г. Екатеринбуре. 
DOI 10.38097/AFA.2020.77.59.009 